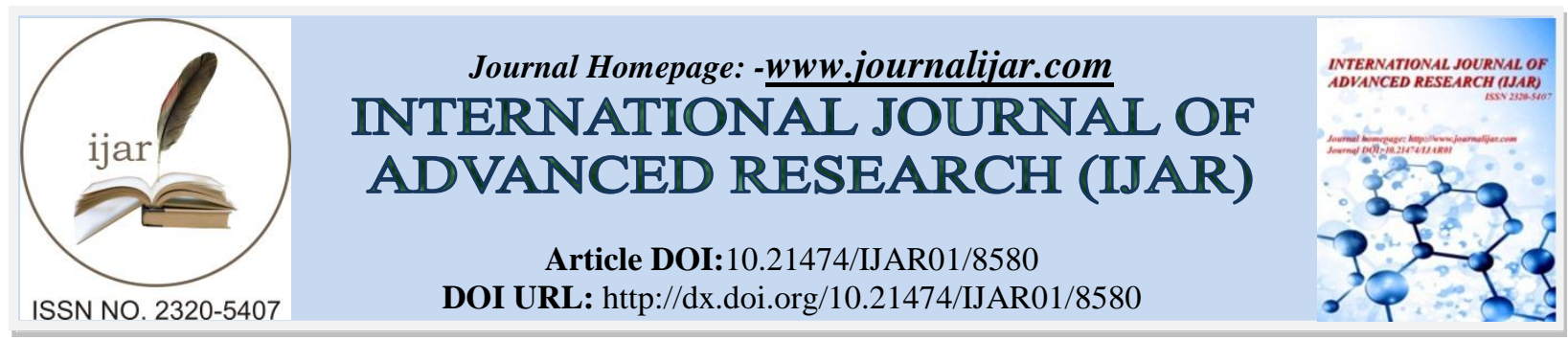

RESEARCH ARTICLE

\title{
LINKING EFFECTIVE PROFESSIONAL DEVELOPMENT AND ELEMENTARY MATHEMATICS INSTRUCTION.
}

Kimberly G. Williams ${ }^{1}$ and Karen S. DiBella ${ }^{2}$.

1. The University of Tennessee at Martin 239D Gooch Hall Martin, TN 38238 United States 731-881-7202.

2. The University of Tennessee at Martin 239B Gooch Hall Martin, TN 38238 United States 731-881-7496.

\section{Manuscript Info}

Manuscript History

Received: 14 December 2018

Final Accepted: 16 January 2019

Published: February 2019

Key words:-

professional development, mathematics instruction, manipulatives, literacy.

\begin{abstract}
This study examined teachers' perceptions of the effectiveness of a hands-on workshop focused on mathematics instructions in a literacyfocused environment. The research institute was provided funding from the Teacher Quality Partnership (TQP) grant provided by the U.S. Department of Education. Summer workshops were one component of the grant, which targeted improvement of the University's Educator Preparation Program (EPP) and strengthening practices of in-service teachers. Results indicate that teachers exhibited higher confidence levels in engaging students in mathematical activities focused on hands-on learning. Additionally, confidence levels of all participants increased in terms of incorporating literacy into mathematics. Data from this study provides evidence that effective professional development, engagement of participants in learning, and modeling of effective practices improves the confidence levels of practicing educators.
\end{abstract}

Copy Right, IJAR, 2019,. All rights reserved.

\section{Introduction:-}

It is important that educators model hands-on, interactive strategies to help students better understand mathematical concepts. Elementary mathematical concepts can be challenging for many students and it is critical that they understand why something works in math, not just how (James, 2016). Creating a classroom environment that is conducive to learning and provides a safe space for students to take risks, ask questions, and actively learn through inquiry-based learning (Zwiers\& Crawford, 2011) is critically important to support student learning. In addition, it is important to employ modeling strategies as it can transform abstract concepts into concrete applications; it can make learning visible (Cohen, 2018). Researchers sought to model mathematical strategies through a hands-on workshopfor elementary teachers, where learning was made visible through interactive engagement.

\section{Review of Literature:-}

Learning is often considered a social skill. Active learning theories stress the social elements of learning, which includes collaborative problem-solving, cooperative action, and dialogues, discussions, and mutually shared reflections (Niemi, 2002).The shift from basic calculations to rigorous problem solving is the foundation of today's mathematics instruction. According to Larson, et al., (2012) "to comprehend problems effectively, students have to employ strategies they have learned during reading instruction ... [which] include identifying relevant details, noting relationships, predicting, making inferences, synthesizing, visualizing, and distinguishing between mathematics

Corresponding Author:-Kimberly G. Williams.

Address:-The University of Tennessee at Martin 239D Gooch Hall Martin, TN 38238 United States 731-881-7202. 
terms and general vocabulary" (p. 30). It is important that teachers help students acquire mathematical language (NCTM, 2000). Providing supports for students is an integral part of teaching and overall student success.

Supporting student learning can take many forms, but one critical way is to differentiate instruction: meet the needs of all students. Teachers who differentiate instruction respond to students' needs in how the content is presented (content), the way it is learned (process), and the way students respond (product) (Dixon, et al., 2014). It is widely accepted that all students do not learn in the same manner; teaching is not a one size fits all approach. Teachers must adjust the curriculum and also the instructional strategies, or supports according to the various needs of students (Tomlinson \& Jarvis, 2009). Professional development that models differentiated instruction, encourages collaborative discussions, and provides experiential learning opportunities can help provide educators with much needed support and instructional strategies that can be easily applied to their classrooms.

Literature supports collaborative learning and it is often linked to improvements in teaching and learning outcomes (Song, Hur, \& Kwon, 2018). In fact, Hill et al (2010) suggest that teachers develop expertise not as isolated individuals but through job-embedded professional development. More importantly, when teachers have contentfocused professional development, they can better understand new instructional approaches, reflect more deeply about their own practices, and make substantive changes in their instructional practices (Brown, Shaffer, \& Werner, 2016; Desimone \& Park, 2017; Libbee, Mater, \&Schaftenaar, 2011). Quality professional development can provide support for teachers and impact their learning and teaching. Teachers, much like students, often learn best from a collaborative, hands-on approach that can easily be applied to their classroom.

\section{Overview and Methodology:-}

Rigorous mathematical instruction requires intensive hands-on instruction through a problem-solving lens; therefore, professional development opportunities must provide an opportunity for participants to engage in student-centered activities. This research study focuses on the analysis of Likert-scale data and open-ended prompts colleted from a 2018 STEM Summer workshop, funded as part of a Teacher Quality Partnership (TQP) Grant. Research of effective professional development, content literacy, active learning, and manipulatives provided the foundation for a mathematics workshop that provided an impetus for change in the elementary mathematics classroom. Researchers engaged in this mixed methods study to answer the following questions:

Research Question 1: "How does a summer workshop focused on elementary instructional strategies impact participant confidence levels?"

Research Question 2: "How will the integration of literacy strategies and manipulatives impact classroom instruction?"

Summer workshops were divided into distinct grade levels in an effort to individualize the instructional activities. Twenty-nine partnering districts were afforded the opportunity to sign up for the workshops on a first-come, firstserved basis. Within a 24-hour period, all workshops were filled to capacity. The workshops were focused on operations and algebraic thinking for pre-K though first grade; operations and algebraic thinking for second and third grade; operations and algebraic thinking for fourth and fifth grade; and fractions for fourth and fifth grade. Topics were chosen based on a needs-assessment that was distributed to elementary teachers in partnering school districts. All hands-on activities were specific to problematic mathematics standards indicated by survey data. Although there was availability for 60 participants, some educators chose to attend multiple sessions to address the needs of their students. Post-workshop survey data was collected from twenty-eight participants as displayed in Table 1.

Table 1:-Sample Population.

\begin{tabular}{|l|l|l|l|l|l|l|}
\hline Years Teaching & & $1-4$ & $5-8$ & $9-12$ & $13-20$ & +20 \\
\hline $\begin{array}{l}\text { Grades Pre-K-1 } \\
(\mathrm{n}=9)\end{array}$ & 4 & 0 & 2 & 1 & 2 \\
\hline $\begin{array}{l}\text { Grades 2-3 } \\
(\mathrm{n}=5)\end{array}$ & & & & 2 & 2 & 1 \\
\hline $\begin{array}{l}\text { Grades 4-5 } \\
(\mathrm{n}=13)\end{array}$ & & 5 & 3 & 2 & 2 & 1 \\
\hline
\end{tabular}




\begin{tabular}{|l|l|l|l|l|l|}
\hline $\begin{array}{l}\text { Special Education } \\
(\mathrm{n}=1)\end{array}$ & & 1 & & & \\
\hline Total $(\mathrm{n}=28)$ & 9 & 4 & 6 & 5 & 4 \\
\hline
\end{tabular}

Participants were exposed to a one-day training on literacy strategies and use of manipulatives in mathematics instruction in a simulated teaching environment. Activities were standards-based and were indicative of "best teaching practices" which integrated literacy, hands-on learning, technology, and problem-solving applications. The workshops were facilitated by the grant project directors to ensure participants were exposed to multiple teaching strategies and were able to use the materials provided in their classrooms immediately. Participants engaged in cooperative learning activities, created a mathematics journal documenting each activity, meaningful and purposeful activities to build academic vocabulary and centers focused on differentiated instruction and student engagement. Additionally, participants received strategies to incorporate literacy into mathematics, analyzed resources to determine text complexity, and created activities for immediately use in the classroom. At the conclusion of each workshop, participants received a classroom set of manipulatives, mathematical readers, and activity resources.

Prior to the distribution of materials at each workshop, participants were asked to complete an anonymous survey to determine if there was a significant effect on teacher attitudes as a result of the summer workshop. Data was collected using an 8-item Likert-scale survey and six open-ended questions. The anonymous surveys were analyzed to determine if the summer workshops offered by UT Martin were effective and also to determine if changes in teacher attitudes occurred in the post-test meaure.Participants responded to each prompt to indicate if their confidence level increased signficantly, increased somewhat, remained the same, or decreased. Likert-scale data was analyzed to answer the following the first research question as follows: "How does a summer workshop focused on elementary instructional strategies impact participant confidence levels?"Table 2 provides the findings of the quantiative responses. All participants indicated that their confidence levels had improved in reference to motivating students in mathematics, incorporating literacy into mathematics, making cross-curricular connections, and incroporating manipulatives into instruction.

Table 2:-Summary of Elementary Mathematics Post-Workshop Summary of Teacher Attitudes

\begin{tabular}{|l|l|l|l|l|}
\hline $\begin{array}{l}\text { After attending this workshop, indicate if your confidence } \\
\text { level: }\end{array}$ & ISIG & ISOME & SAME & DEC \\
\hline I can motivate students to learn in mathematics. & $61 \%$ & $39 \%$ & & \\
\hline I can incorporate literacy into mathematics. & $75 \%$ & $25 \%$ & & \\
\hline I can help students develop effective problem-solving skills. & $54 \%$ & $43 \%$ & $3 \%$ & \\
\hline I can make cross-curricular connections. & $64 \%$ & $36 \%$ & & \\
\hline I can identify student misconceptions in mathematics. & $36 \%$ & $50 \%$ & $14 \%$ & \\
\hline $\begin{array}{l}\text { I can help students who are struggling with mathematics make } \\
\text { sense of the content. }\end{array}$ & $61 \%$ & $28 \%$ & $11 \%$ & \\
\hline $\begin{array}{l}\text { I can help students who are struggling with mathematical } \\
\text { foundational skills. }\end{array}$ & $61 \%$ & $32 \%$ & $7 \%$ & \\
\hline $\begin{array}{l}\text { I can incorporate manipulatives to help students with conceptual } \\
\text { understanding. }\end{array}$ & $79 \%$ & $11 \%$ & & \\
\hline Not
\end{tabular}

Note:-ISIG=Increased Significantly; ISOME=Increased Somewhat; SAME=Remained the Same; DEC=Decreased

Researchers also used a qualitative analysis to delve deeply in the open-ended responses to determine the following:

Research Question 2: "How will the integration of literacy strategies and manipulatives impact classroom instruction?"Qualitative analysis revealed two primary themes, which correlated to the quantitative results, as follows:

1. Theme 1: Participants discussed the value of using manipulatives to engage students.

2. Theme 2: Participants discussed the value of incorporating literacy in the mathematics classroom to differentiate instruction.

Additionally, 96 percent of participants indicated that they believe the STEM summer workshop would have a positive impact on student performance. One participant commented, "The idea of centers initially frightened me. This [professional development] showed me ways to use centers effectively." Additional comments supported the 
meeting varied needs of students and the effective use of manipulatives. "I learned different methods, strategies, and concepts to incorporate with my students. With this, I can present content and have them practice in various ways, meeting the learning needs of my students!" stated one participant. Another stated, "This workshop has provided me with the materials to give students hands-on activities that will make student learning fun." Many other comments supported the use of literacy in the classroom and personal connections to the activities currently being used in the classroom. One participant explicitly stated, "I am motivated to incorporate more literacy into my math class so my students will have more exposure."

\section{Discussion and Conclusion:-}

This mixed methods study provides data that strongly supports the value of targeted professional development, which provided participants an opportunity to engage in the role of the student. Educators, just like students, have varied learning needs and without quality professional development opportunities, they will not have the opportunity to continue to improve their practice. Researchers sought to determine areas of strengths and also areas where additional support is needed. Participant responses to identifying misconceptions in mathematics and developing intervention strategies indicate that the workshops did not target those areas specifically or the connection was not made between the activities and how those could be used as interventions. This provides an area for follow-up professional development and support for teachers in partnering districts.

Researchers intend to continue to offer workshops focused on effective instructional strategies for both elementary and secondary mathematics in-service and pre-service teachers. Additional considerations are to ensure follow-up opportunities are provided for continual growth.As educators, we must continue to model, implement, and assess the practices we implement into our classrooms to ensure we create future teachers who will use quality instructional strategies to support the varied needs of today's twenty-first century learners.

\section{References:-}

1. Brown, K., Shaffer, L., \& Werner, S. (2016). An analysis of how building a collaborative Community of professional social studies teachers through targeted ambient

2. Professional development impacts social studies classroom practices. Journal of Education and Training Studies, 4(11), 58-72.

3. Cohen, J. (2017). Practices that cross disciplines: Revisiting explicit instruction in elementary mathematics and English language arts. Teaching and Teacher Education 69, 324-335.

4. Desimone, L. \& Park, K. (2017). Instructional coaching as high-quality professional Development. Theory into Practice 56(1), 3-12.

5. Dixon, F.A., Yssel, N., McConnell, J.M., \& Hardin, T. (2014). Differentiated instruction,Professional development, and teacher efficacy. Journal for the Education of the Gifted 37 (2), 111-127.

6. Hill, D.J., Jeffrey, P., McWalters, K., Paliokas, A., Seagren, \& C. Stumbo. (2010).

7. Transforming teaching and leading: A vision for a high-quality educator Development system. Washington DC: Council of Chief State School Officers.

8. James, L. (2016). Mathematics awareness through technology, teamwork, engagement, and rigor. Journal of Curriculum and Teaching (5), 2, 55-60.

9. Larson, M.R., Fennell, F., Adams, T. L. Dixon, J.K., Kobett, B.M., \& Wray, J.A. (2012).

10. Common Core Mathematics in a PLC at Work. Bloomington, IN.: Solution Tree Press.

11. Libbee, M., Mater, M., \&Schaftenaar, I. (2011). Can professional development enhance

12. Student achievement and prove it? Results of the 1999-2003 Michigan Achievement

13. Project. In Geographic literacy in the United States: Challenges and Opportunities In the NCLB Era, edit4ed by G.S. Elbow, D.J. Rutherford, and C. Shearer, 38-44.

14. New York: National Council for Geographic Education.

15. National Council for Teachers of Mathematics (2000). Principles and standards for school mathematics. Reston, VA: NCTM.

16. Niemi, H. (2002). Active learning - a cultural change needed in teacher education and schools. Teaching and Teacher Education (18),763-780.

17. Song, K., Hur, E. \& Kwon, B. (2018). Does high-quality professional development make a difference? Evidence from TIMSS. Compare: A Journal of Comparative and International Education (48)6, 954-972. 
18. Tomlinson, C.A. \& Jarvis, J. (2009). Differentiation: Making curriculum work for all Students through responsive planning and instruction. In J.S. Renzulli, E.J. Gubbins, K.S. McMillen, R.D. Eckert, \& C.A. Little (Eds.), Systems and models for

19. Developing programs for the gifted and talented (pp. 599-628). Storrs, CT: Creative Learning Press.

20. Zwiers, J. \& Crawford, M. (2011). Academic conversations: Classroom talk that fosters critical thinking and content understandings. Portland, MA: Stenhouse, (7-31). 